\title{
QUALITY ASSESSMENT OF SURFACE AND GROUNDWATER IN THE VICINITY OF "ELESHNITSA" TAILING POND, BULGARIA
}

DOI: https://doi.org/10.18509/AGB.2017.05

UDC: $556.3 / .5 .08: 504.3 / .6(497.2)$

\author{
Sava Kolev ${ }^{1}$ \\ ${ }^{1}$ Geological Institute, Bulgarian Academy of Sciences, Bulgaria \\ Corresponding author: sava_kolev@geology.bas.bg \\ Submitted: January 2017, Accepted: April 2017, Published: August 2017
}

\begin{abstract}
The Eleshnitsa uranium mine near Razlog, SW Bulgaria was in operation from 1955 to 1992 and the uranium ore was enriched at the milling plant near the mine. At this time a tailing pond was exploited since 1969. Its construction took place by blocking the natural depression of the Vulche dere creek by a dam. This tailing pond was an object of an EU-sponsored rehabilitation project that started in 2003 and lasted for about 2 years. As a result, a purification station collects all the drainage water downstream from the tailing pond and treats it for possible uranium pollution. The present study considers the variation in the chemical components concentrations in the surface water of Vulche dere creek downstream from the tailing pond, and in depth in groundwater of the Quaternary and the Neogene aquifers. The analysis of the results allows to evaluate the influence of the tailing pond and shows an evident hydraulic interaction between surface water and groundwater. It is compared also the influence of the tributaries of Vulche dere creek on the chemical composition of water during the dry and wet season.
\end{abstract}

Key words: Eleshnitsa, tailing pond, water quality, surface-groundwater interaction;

\section{Introduction}

Eleshnitsa uranium mine (called "Druzhba") near Razlog was under operation from 1955 to 1992 and the uranium ore was enriched at the milling plant (called "Zvezda") in the vicinity of the mine or sent to the milling plant of Buhovo (near Sofia) [1]. The discovery of uranium in sandstone was made in the early 1950's [2], it is located in the molasse sediments of Oligocene age that are produced by the erosion of the Rila and Pirin mountain ranges. Uranium in the ore was predominantly present in primary uranium minerals such as uraninite and coffinite, as well as in secondary mineral phases like autunite, torbernite and uranophane [3]. It was an underground mine and the ore was extracted mostly by pit excavation and heap leaching at the surface, but leaching in-situ also occurred on at least two occasions. At that time a tailing pond was exploited since 1969. This pond, situated 2,6 km south east of the village of Eleshnitsa (Figure 1), start- ed operations in 1969. Its construction took place by blocking the natural depression of the Vulche dere creek by an earth-fill dam [4]. Currently, the height of the dam is $74 \mathrm{~m}$ and the surface area of the tailing pond is $250000 \mathrm{~m}^{2}$. The pond contains about 9 million tons of hydrometallurgical wastes [5], including around 730 tons of uranium [6]. The total radio-activity is estimated to be about $1,5 \times 10^{15} \mathrm{~Bq}$ [7]. This tailing pond was an object of an EU-sponsored rehabilitation project (PHARE BG 9904-03-01-02) that started in 2003 and lasted for about 2 years. A purification station downstream from the tailing pond has been collecting all the drainage water and treats it for possible uranium pollution since 2005. After purification the water flows into Vulche dere creek, a tributary of Mesta River. Additionally, two piezometers were installed in 2002 at the valley of Vulche dere creek - one among Quaternary sediments, with depth of $20 \mathrm{~m}$ (piezometer B3-25) and the other one (piezometer B3-26) with depth of $135 \mathrm{~m}-$ in 
Neogene. The data collected before 2012 has significant gaps of information about concentrations of cations and no any available data is obtained for flow rates of Vulche dere creek and water levels in the piezometers. The study performed in 2012 shows influence of the tailing pond on the surface water of Vulche dere creek and the groundwater in the Quaternary aquifer, where are detected enhanced concentrations of nitrates and sulfates. There is no any influence on the surface water of Mesta River and the groundwater in the Neogene aquifer [8]. The aim of this article is to evaluate the influence of the tailing pond during dry and wet season. Variation of the chemical component concentrations in surface water and groundwater along downstream from the tailing pond will be taken under consideration.

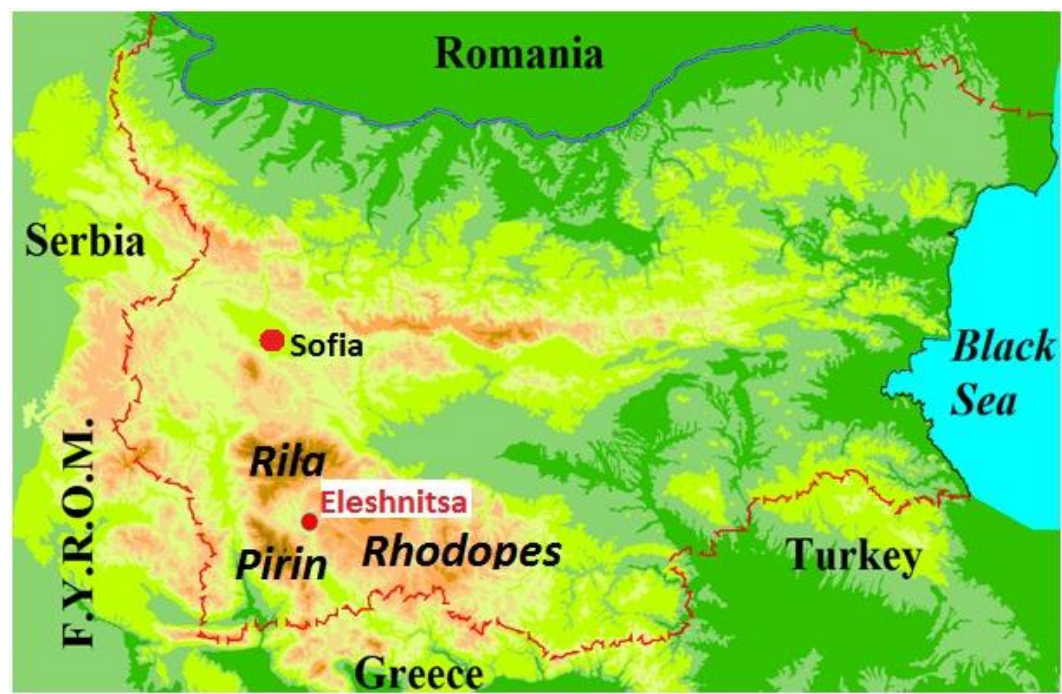

Figure 1: Location of the village of Eleshnitsa

\section{Study area}

"Eleshnitsa" tailing pond is situated among the valley of Vulche dere creek (Figure 2). The purification plant is situated at the foot of the dam. One of the significant left tributary, Bishir dere creek, recharges Vulche dere creek which further flows into Mesta
River. The distance between the purification plant and Mesta River is about $1200 \mathrm{~m}$. The two piezometers are installed nearby Vulche dere creek approximately $100 \mathrm{~m}$ away of Mesta River.

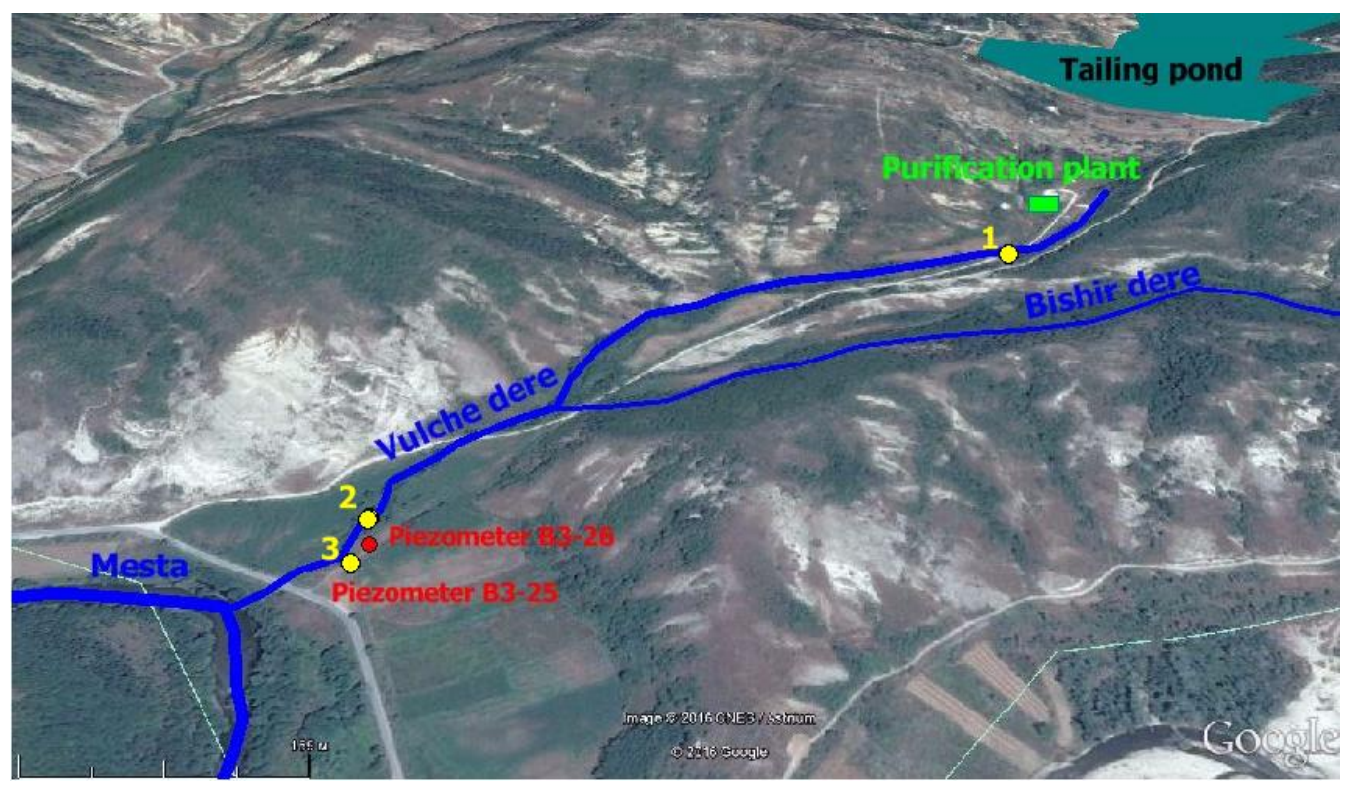

Figure 2: Scheme of the valley of Vulche dere creek with location of sampling points.

1 - Vulche dere creek after purification plant, 2 - Vulche dere creek near piezometers, 


\section{Methods and materials}

Four sampling campaigns took place during the period 2012 - 2016. The field activities included sampling of surface water from Vulche dere creek at two points - after the purification plant and near the piezometers, as well as groundwater from piezometer B325 (Figure 2). Physical-chemical variables in the water such as temperature, $\mathrm{pH}$ and total alkalinity were measured in-situ. Temperature and $\mathrm{pH}$ were measured by YSI Professional Plus multiparameter meter. Total alkalinity is determined by titration, using a dilute hydrochloric acid $(\mathrm{HCl})$ solution to neutralize the sample to a $\mathrm{pH}$ of 4,5 and a phenolphthalein indicator. Water samples were collected in pre-cleaned plastic bottles. Both anions and cations samples were filtered through $0,45 \mu \mathrm{m}$ filter and the cations samples were acidified with $\mathrm{HCl}$. Flow rates were measured using Seba Mini Current Meter M1 and the groundwater levels were measured by standard dip meter. Chemical component concentrations were analyzed by the Dosimetric and engineering-aerological laboratory (DIAL Ltd) - Buhovo. The regulatory trespassing of the analyzed samples is determined according to Bulgarian regulation.

\section{Results and discussion}

Comparing the quantitative indicators (measured flow rates of Vulche dere creek and groundwater levels in piezometer B3$25)$ with variation of chemical composition of the water for the period $2012-2016$ (Figure 3, 4, 5) shows similar behavior in the three monitoring points. Higher concentrations are reached when there are lower water levels and reduced flow rates (November 2012 and August 2016) and dilution of pollutants is extremely weak. This is confirmed by the fact that at the time of wet period there are not any exceedances in the contents of sulfates and nitrates according to the Norm № 7/08.08.1986 on indicators and standards for determining the quality of flowing surface water (Figure 6,7).

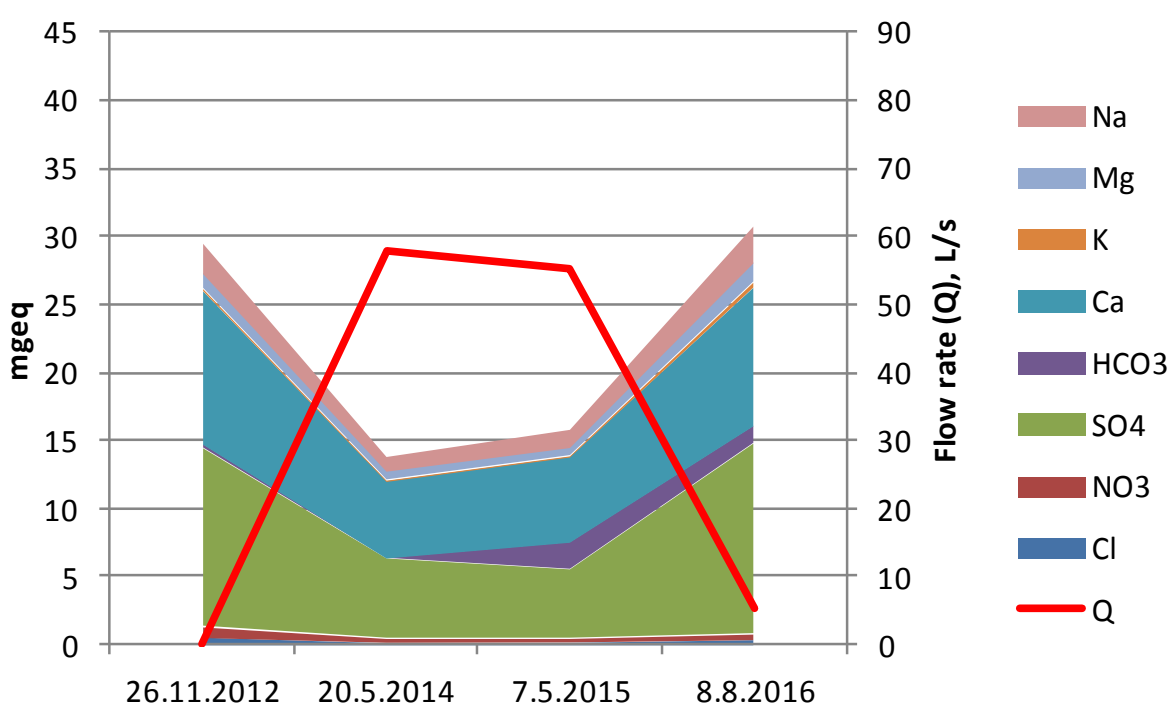

Figure 3: Chemical components and flow rate variation in Vulche dere creek after purification plant 


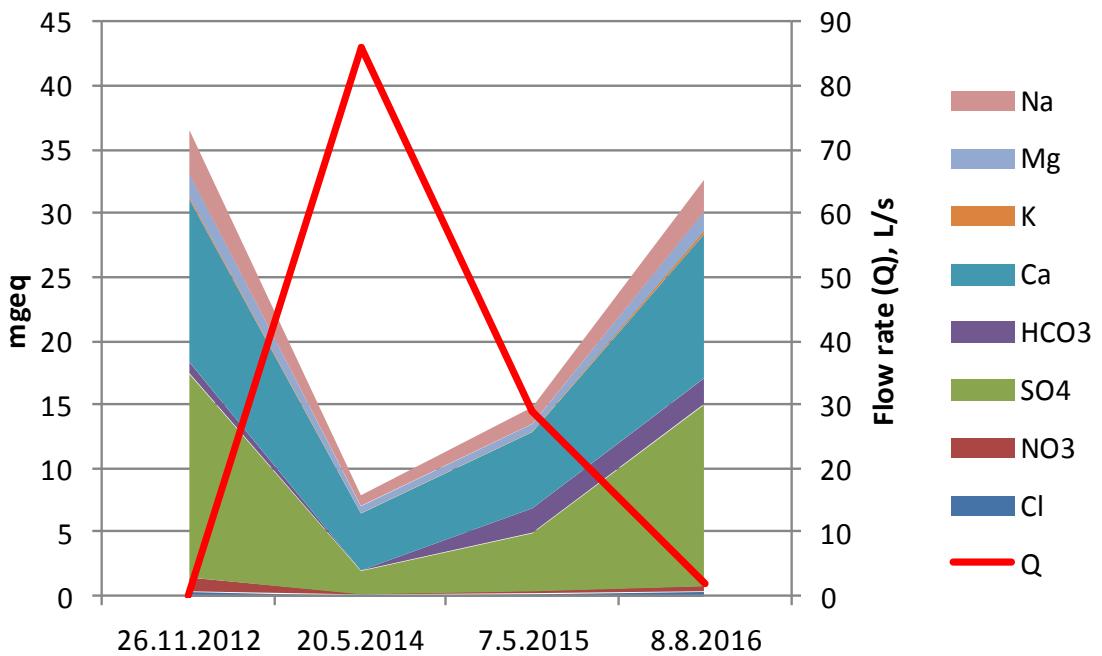

Figure 4: Chemical components and flow rate variation in Vulche dere creek near piezometers
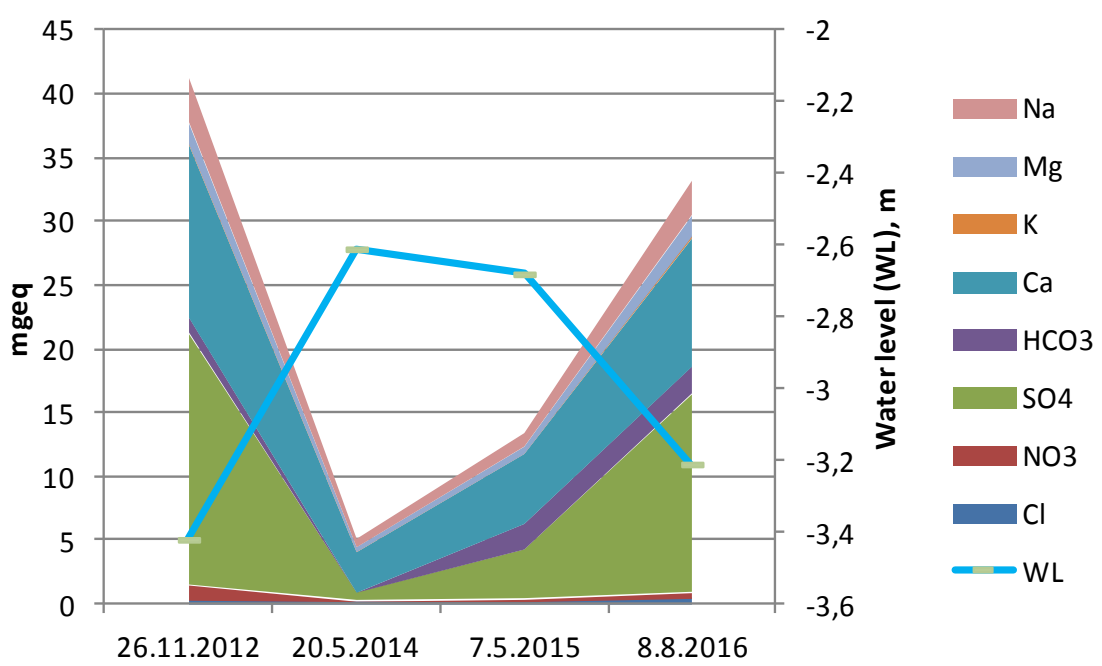

Figure 5: Chemical components and water level variation in Piezometer B3-25

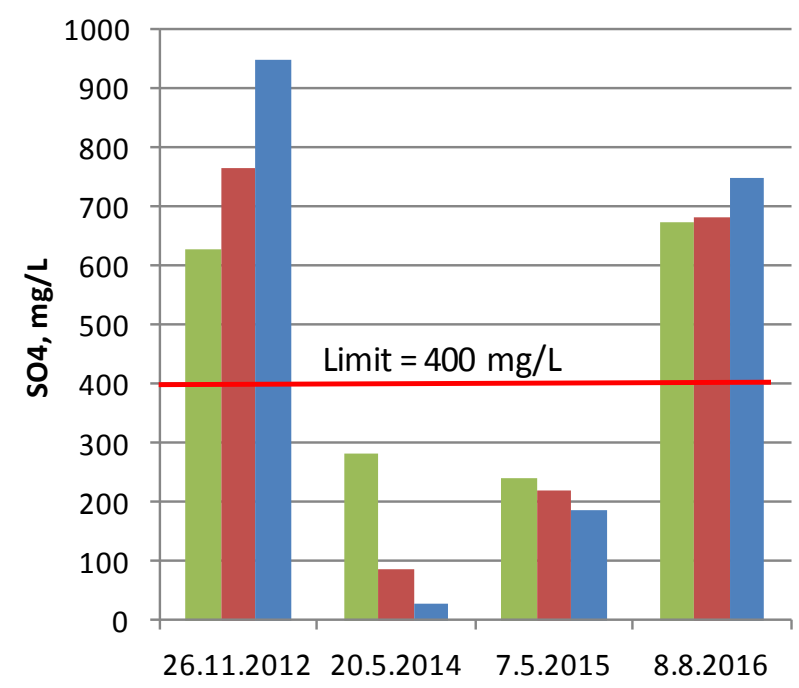

Vulche dere after purification plant

Vulche dere near piezometers

Piezometer B3-25

Figure 6: Sulfate concentrations comparing to regulatory limit by sampling point 


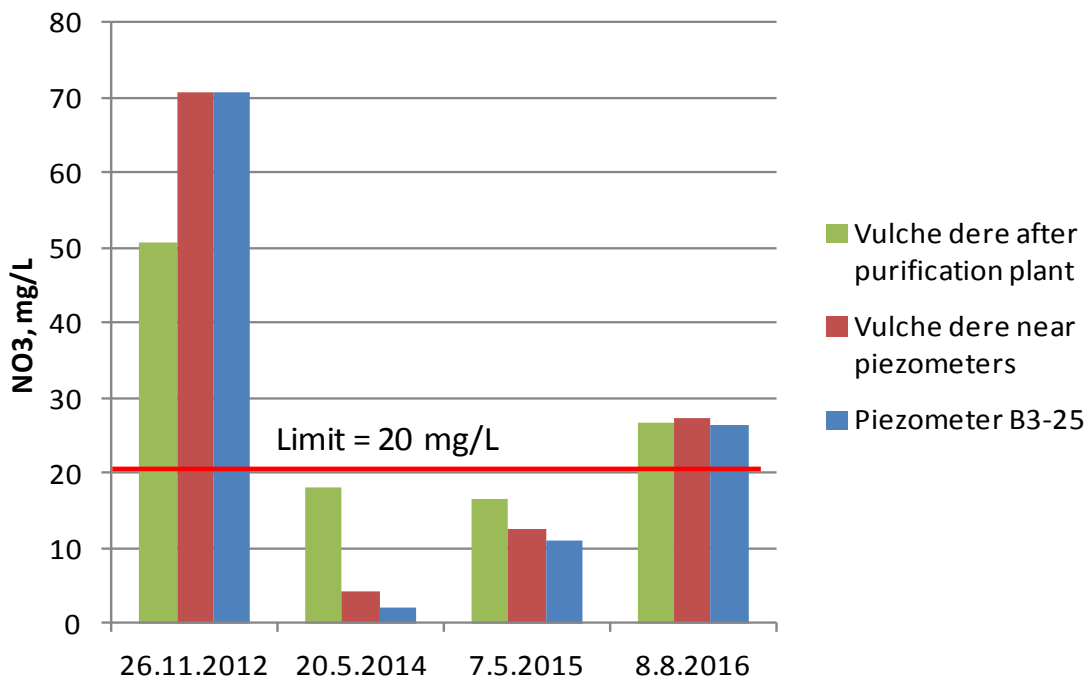

Figure 7: Nitrate concentrations comparing to

regulatory limit by sampling point

The outflow from the tailing pond seems to be relatively stable as regards to TDS (total dissolved solids) and chemical components composition. Apparently, the treatment of the water in the purification plant in high degree leads to unification of its chemical composition during different seasons.

Downstream, near the piezometers, during dry seasons and low water stands the water has higher TDS comparing to the water treated in the purification plant. Obviously, the source of this high TDS is not the tailing pond but probably some residual old pollution from the period before the rehabilitation of the tailing pond caused it. The higher amount of precipitation and inflowing tributary water leads to high water stands and refreshment of the water of Vulche dere creek and changes its type during wet sea- son. Thus, the climate factors act purification role through dilution of pollutants.

TDS during dry season is even higher in the piezometer than nearby creek. There is probably a higher TDS in the Quaternary aquifer because of the stagnant regime of the groundwater. There is fast refreshment of the groundwater during wet season. It seems that unsaturated zone is high permeable and it is observed fast infiltration of surface water.

The fast surface-groundwater hydraulic interaction is confirmed by the similar behavior of the sulfates and nitrates in the three monitoring points (Figure 8, 9), which is found out in all measurements.

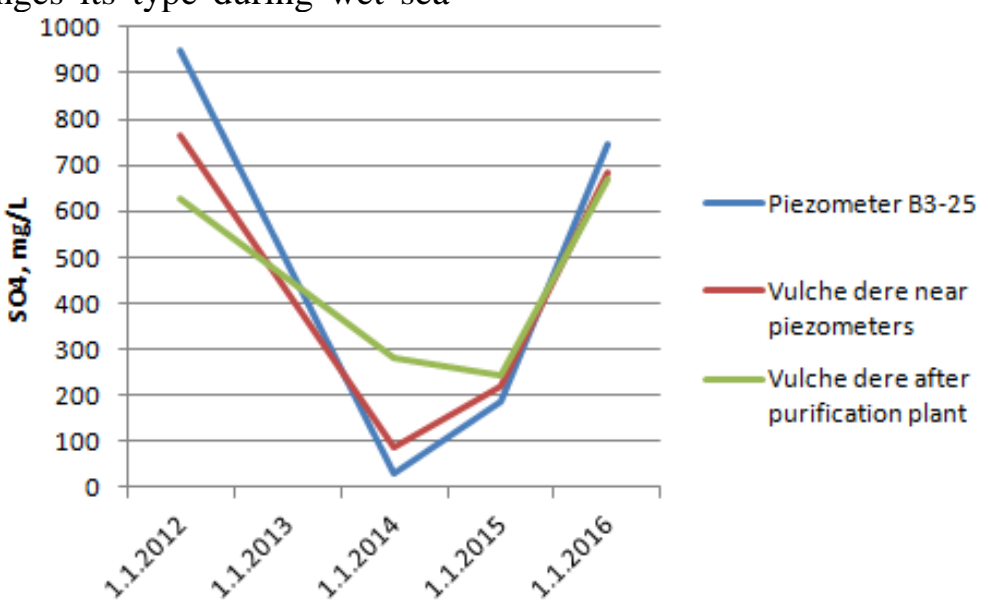

Figure 8: Sulfate concentrations variation over time 


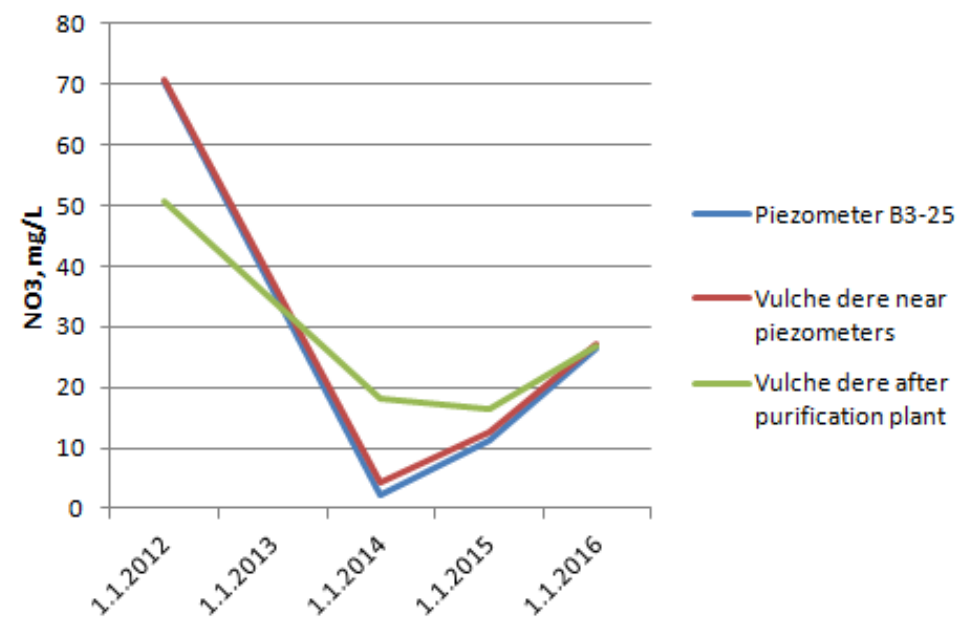

Figure 9: Nitrate concentrations variation over time

Evidence for the presence of residual old pollution in the Quaternary aquifer is the variation in concentrations of sulfates downstream the creek as well in depth (Figure $10)$. It is clearly visible that during dry season (November 2012 and August 2016) the content of sulfates is higher downstream and in groundwater whereas during wet season it is reduced because of dilution. The same behavior is observed in the concentration variations of nitrate, calcium, magnesium, sodium, and also some micro-components as cadmium and lead. As regards to manganese and iron, the diagrams are contradictory. That is probably due to their dependence on redox reactions and more detailed study is needed for complete understanding of their seasonal variation.

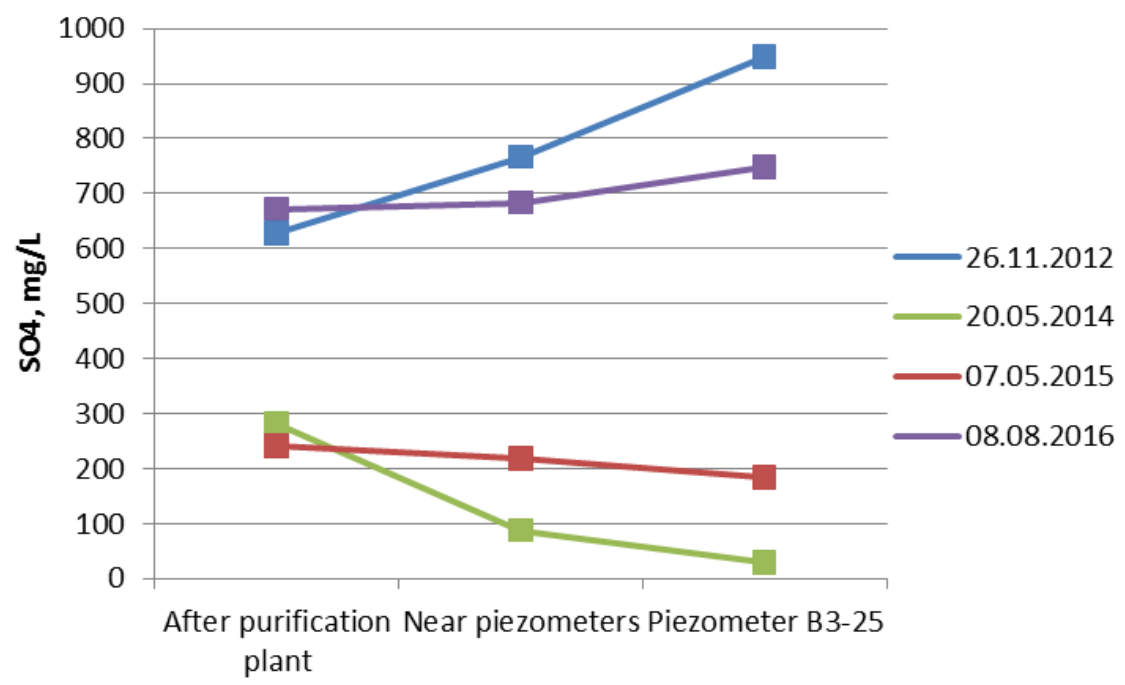

Figure 10: Sulfate concentrations variation along Vulche dere creek and in depth in Quaternary aquifer

\section{Conclusion}

The results of the study show that there are natural and technogenic factors which reflect on the chemical composition of surface and groundwater in the studied area. The natural factors include the changes in the amount of precipitation and in the recharge of Vulche dere creek. The technogenic factors are the influence of the tailing pond and the alleged old residual pollution.
During wet season there is dilution of pollutants and no exceedances of the regulatory limits are observed. The behavior of sulfates and nitrates shows that there is evident surface-groundwater hydraulic interaction which is prerequisite for fast refreshment of groundwater during that season. During dry season there are enhanced pollutants concentrations which source is not the tailing pond 
but probably some residual old pollution in the Quaternary aquifer.

The obtained results could serve as basis for future establishment of more detailed monitoring and for predicting of the risk of pollution of surface and groundwater, taking into account both the technogenic and natural factors.

\section{Acknowledgments}

This study was funded by Bulgarian Academy of Sciences in the frames of "Programme for support of young scientists in the Bulgarian Academy of Sciences".

\section{References}

[1] IAEA-TECDOC-1088. 1999. Technical options for the remediation of contaminated groundwater. Annex VI: Radioactively contaminated land areas and waters in Bulgaria, p. 105-109.

[2] Simov, S. Uranium Exploration in Bulgaria - a review. IAEA TECDOC-597. Assessment of uranium resources and supply. Proceedings of the technical committee meeting held in Vienna 29 August - 1 September 1989: 41-48; 1989.

[3] Stoykov H., I. Bozhkov. Uranium deposits. Geology and search. Sofia: Spektar; 1991.

[4] Christiansson, R. 1998. Closedown Programme for the Uranium Ore and Resin processing Plant at Eleshnitsa, Bulgaria. Detailed Design Report. 30 April, 1998.

[5] Fourth national report for fulfilling the obligations under the Joint Convention for safety management of spent fuel and safety of radioactive waste. Sofia, 2011.

[6] Working project for building of local environment monitoring net in the region of uranium mine (MDP "Druzhba") and plant "Zvezda" - Eleshnitsa, January 2000.

[7] Dimitrov M., E. Vapirev. Uranium industry in Bulgaria and environment: problems and specific features of the period of technical close-out and remediation of the negative consequences. In: IAEA TECDOC-865. Planning for environmental restoration of radioactively contaminated sites in central and eastern Europe. Volume 2: Planning for environmental restoration of contaminated sites. Proceedings of a workshop held within the Technical Co-operation Project on environmental restoration in Central and Eastern Europe in Piestany, Slovakia, 11-15 April 1994: 43-53, 1994.

[8] Kolev, S., N. Van Meir, Kr. Ivanova. 2014. Assessment of the current state of radionuclides and metals content in the surface and groundwater at the region of Eleshnitsa former uranium mine. Radiation Protection Journal, 2, 2014, 35-42, ISSN: 1314-9199. 